\title{
In vitro Efficacy of Bio-control Agents against Mycosphaerella musicola causing Sigatoka Leaf Spot of Banana
}

\author{
R. Guru Nandan Kumar*, J. P. Mishra and Rajendra Prasad \\ Department of Plant Pathology, School of Agricultural, Uttaranchal University, \\ Dehradun-248007, Uttarakhand, India \\ *Corresponding author
}

\section{A B S T R A C T}

\section{Keywords \\ Bio-agents, \\ Sigatoka leaf spot, \\ Banana, \\ Trichoderma and \\ M.musicola \\ Article Info \\ Accepted: \\ 14 June 2020 \\ Available Online: \\ 10 July 2020}

\section{Introduction}

A banana botanically an edible berry fruit, produced in the Musa genus, by several varieties of a huge herbaceous flowering plants. In some nations, bananas used in cooking may be labeled "plantains," separating them from bananas used in dessert. The fruit differs for scale, colour and steadiness; nearly all conventional edible seedless bananas (parthenocarp) that came from two wild species, which might be Musa acuminata and Musa balbisiana, Most cultivated bananas' scientific names include Musa acuminata, Musa balbisiana, and Musa alparadisiaca for hybrid Musa acuminata al M. Balbisiana, based on its genetic makeup. The traditional scientific description name Musa sapientum not in use during now a day.

Musa species are local to tropical IndoMalaya, Australia and are believed to have been domesticated for the first time in country Papua New Guinea. They are cultivated in 135 countries, mainly for their berries, and to a less extent to provide sugar, banana and banana ber and also like ornamental plants. India and China were the world's largest growers of bananas in 2017. 
In 2017 , the overall global banana production and plantains was stated as 153 million tonnes, driven by India \&China with a collective total of 27 per cent of global production [needed to be cited]. The Philippines, Venezuela, Malaysia, Ecuador and Brazil were also major producer

Sigatoka disease or banana leaf spot exists throughout the world and is one of the most damaging diseases of banana. The disease was first reported in Java in 1902 (Zimmerman, 1902) and, its first outbreak occurred in the sigatoka valley of Fiji in 1913, hence the same sigatoka. In India, it is one of the country's major diseases that exist in various banana growing regions.

Sigatoka disease is caused by fungus Mycosphaerella musicola. Features of the disease include the presence of abundant discrete spots on older leaf lamina. Young leaves are spot-free. The spots grow to 1 or 2 $\mathrm{cm}$ in length after a few days, and turn brown with light gray centers. An equally broad spot on the lower leaves develop, the spots spread and turn yellow and die. There are also black specks on the upper surface of the light-gray patch. On which the conidia of the fungus are raised. The attack on the lamina is a serious degradation of the disease (Agrios, 1997)

\section{Materials and Methods}

The research on Sigatoka leaf spot (Mycosphaerella musicola) of banana was carried out in the Plant Pathology Lab, Uttaranchal School of Agricultural, Uttaranchal University, Dehradun, Uttarakhand, India. (2019-2020)

\section{Isolation of the pathogen}

The causal organism, M.musicola was isolated from banana leaves showing the typical leaf spot symptoms of the disease. The infected leaves were cut in to small leaf bits and surface sterilized with one per cent sodium hypochlorite solution for 2-3 minutes and 3 times repeatedly washed in sterilized distilled water. Then the infected leaf bits were transferred on to Petri dishes (1-2 leaf bits per Petri plate) containing PDA with the help of a sterile forceps and incubated at $25^{\circ} \mathrm{C}$ for 10 days Further purification and sub culturing were done on PDA slants and Petri plates by hyphal tip isolation method.

\section{Hyphal tip isolation}

The method was followed for obtaining pure culture of M.musicola since the fungus is known to be highly heterozygous. Hyphal tip isolation was done on $2 \%$ water agar plates. Diluted hyphal suspensions were prepared in sterile distilled water. One $\mathrm{ml}$ of such suspension was spread uniformly on water agar plates and observed for hyphae under microscope. Single isolated hypha was allowed to germinate. Each plate was incubated at $25 \pm 1{ }^{\circ} \mathrm{C}$ and periodically observed for germination under the microscope. Germinating hyphae was marked using marker and were cut by using cork borer and transferred on to the PDA plates incubated at $25 \pm 1{ }^{\circ} \mathrm{C}$ to get the pure culture. No sectoring was observed in any of the isolates and all of them were found identical in their growth and colony character, Hence it was taken as pure pathogenic culture and was maintained for further studies.

\section{In vitro efficacy of bio-control agents}

$20 \mathrm{ml}$ of sterilized PDA medium was plated in $80 \mathrm{~mm}$ petriplates. Culture disc of fungal bio agent and pathogen were taken from the growing cultures and transferred to PDA contained in $80 \mathrm{~mm}$ petridishes on opposite sides approximately at one $\mathrm{cm}$ from the wall of the plate. For each treatment four replications were maintained and control 
plates were maintained by placing only the pathogen and incubated at $25^{\circ} \mathrm{C}$. The colony growths of the fungal bio agent and test pathogen were recorded by periodical observations.

The percent of inhibition growth was calculated by using the formula-

$$
\mathrm{I}=100(\mathrm{C}-\mathrm{T}) / \mathrm{C}
$$

$\mathrm{I}=$ Percent inhibition of mycelium growth

$\mathrm{C}=$ Growth of mycelium in control

$\mathrm{T}=$ Growth of mycelium in treatment

Three fungal bio agents were tested against M.musicola. The name of three bio agents and their sources were mention in following table:

\section{Results and Discussion}

\section{Experimental Results}

Three fungal bio agents were evaluated against the pathogen M.musicola under in vitro condition. Out of three bio agents, T.viride showed maximum percent growth inhibition $61.87 \%$. The next bio-agent which showed best effective was T.asperellum and showed $57.81 \%$ growth inhibition. The bio agent T.harzianum showed the lowest growth inhibition percent of the pathogen. Among the three species of fungal bio agent T.virideshowed higher antagonism as compared to other two bio agents against the pathogen M.musicola.

Table.1 Name of bio-agents and their sources

\begin{tabular}{|l|l|}
\hline Name of bio agents & Sources \\
\hline Trichoderma viride & $\begin{array}{l}\text { Department of plant pathology, school of } \\
\text { agriculture, Uttaranchal university, Dehradun }\end{array}$ \\
\hline Trichoderma harzianum & $\begin{array}{l}\text { Department of plant pathology, school of } \\
\text { agriculture, Uttaranchal university, Dehradun }\end{array}$ \\
\hline Trichoderma asperellum & $\begin{array}{l}\text { Department of plant pathology, school of } \\
\text { agriculture, Uttaranchal university, Dehradun }\end{array}$ \\
\hline
\end{tabular}

Table.2 In vitro efficacy of bio-agents on mycelial growth of M.musicola

\begin{tabular}{|l|c|}
\hline \multicolumn{2}{|c|}{ Colony growth (mm) on bio agents } \\
\hline Bio-agents & Mean growth recorded \\
\hline Trichoderma viride & 30.50 \\
\hline Trichoderma harzianum & 45.25 \\
\hline Trichoderma asperellum & 33.75 \\
\hline Control & 80 \\
\hline SEM(m) & 1.90 \\
\hline C D & 6.17 \\
\hline
\end{tabular}


Table.3 In vitro efficacy of bio-agents on percentage growth inhibition of M.musicola

\begin{tabular}{|l|c|}
\hline Growth inhibition \% & \\
\hline Bio- agents & Inhibition \% \\
\hline Trichoderma viride & 61.87 \\
\hline Trichoderma harzianum & 43.43 \\
\hline Trichoderma asperellum & 57.81 \\
\hline Control & 00 \\
\hline SEM(m) & 2.38 \\
\hline C D & 7.72 \\
\hline
\end{tabular}

Fig.1 In vitro efficacy of bio-agents on mycelial growth of M.musicola

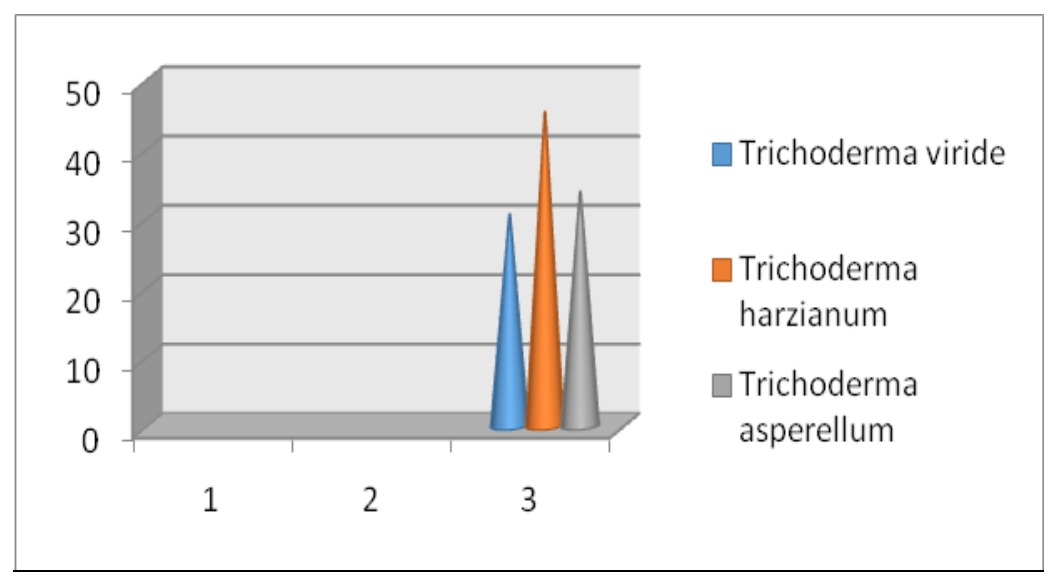

In vitro evaluation of bio-agents

In the present investigation three different bio-agents viz., Trichoderma harzianum, Trichoderma viride and Trichoderma asperellum were tested against M.musicola.

H. Noorulla, M. K. Naik, G. Jadesha and Praveenkumar Yadahalli (2013) reported that Trichoderma harzianum and Trchoderma viride was effective against Cercospora musae.

Abiala M. A, Ogunjobi A.A, Odebode A. C, Ayodele M. A (2010) reported that Trichoderma asperellum was effective than Bacillus subtislis and Trichoderma longibrachiatum against Mycospharella fijensis.
In conclusion this study we revealed that Trichoderma viridae gave best effective against mycelial growth inhibition of M.musicola and it may be used for the control of sigatoka leaf spot of banana.

\section{References}

Abiala M. A, Ogunjobi A.A, Odebode A. C, Ayodele M. A. 2010. Microbial Control of Mycospharella fijensis Morelet A Notable Pathogen of Bananas and Plantains. Nature and Science. 8(10):299-305.

Desmukh, R.V., S.V. Dhutraj and V.P. Damodhar. 2018. Field evaluation of bio-control Agent and phyto-Extract against Intensity of Sigatoka Leaf Spot and Yield of Banana cv. Ardhapuri. 
International Journal of Current Microbiology and Applied Sciences. 6: 101-104.

Dionisio G. A. 2012. Inhibitory influence of biocontrol agents, plant oils and an inorganic salt on Mycospharella fijensis and Cordana musae, the casual pathogen of black sigatoka and leaf spot of banana. African Journal of Microbiology research. 6(19):41794184.

Eneke T. B. and Yannick A. A. 2017. Morphological and molecular identification of fungi associated with corn rot and blight symptoms on plantain (Musa paradisiaca) in macropropagators. Int. J. Biol. Chem. Sci. 11(6):2793-2808.

Khan, M. A. H., I. Hossain and U. Ahmed. 2015. Impact of Weather on Sigatoka Leaf Spot of Banana (Musa spp. L.) and its Ecofriendly Management. The Agriculturists. 13(2):44-53.

Noorulla, H., M. K. Naik, G. Jadesha and Praveenkumar Yadahalli. 2013. Biological control of Cercospora musae- an incitant of Sigatoka disease of banana. J. Pl. Dis. Sci. 8(1):82-85.

\section{How to cite this article:}

R. Guru Nandan Kumar, JP Mishra and Rajendra Prasad 2020. In vitro Efficacy of Bio-control Agents against Mycosphaerella musicola causing Sigatoka Leaf Spot of Banana. Int.J.Curr.Microbiol.App.Sci. 9(07): 1505-1509. doi: https://doi.org/10.20546/ijcmas.2020.907.173 